\title{
ACTUAL ISSUES OF FORMATION OF PROFESSIONAL COMPETENCES OF FUTURE PROFESSIONALS WHEN STUDDING GOOD PHARMACEUTICAL PRACTICES
}

\section{Krychkovska A. M., Hubytska I. I., Lopatynska O. I.}

\section{INTRODUCTION}

The formation of competencies of future professionals for the pharmaceutical field, taking into account the relevance and expectations of potential employers, is an important component in the development of educational-and-professional (EPP) and educational-and-scientific programs (ESP) at all cycles of higher education (HE).

For this reason, the meetings of professors and students with employers, among which "Arterium" Corporation - the leading pharmaceutical enterprise in the region, are held systematically at the Lviv Polytechnic National University.

At one of such meetings, in 2016, precisely the employers of "Arterium" Corporation paid attention to the insufficient knowledge level of the Good Pharmaceutical Practices (GPP) complex in the professional training of pharmacy specialists. Employers noted, first of all, it is necessary to carry out the advanced training the newly hired specialists on this topic. For this purpose, the annual cycles of lectures of leading specialists of the enterprise for senior year's students were organized within the framework of the cooperation. The trainees received appropriate certificates, which were taken into account by the employer when considering applications for internships at the corporation, and this, in turn, fostered future employment.

The Scientific and Methodological Commission of the specialty "Pharmacy, Industrial Pharmacy" conducted the all-round analysis of this problem and as results, the revision and updating of existing EPP and ESP of the three cycles system of HE have been conducted.

It should be noted that according to the Cabinet of Ministers of Ukraine (CMU) Resolution No. 266 of 29.04.2015 "On Approval of the list of branches of study and specialties, for the training of higher education applicants" (with amended), the Order of Ministry of Education and Science of Ukraine No. 1151 of 06.11.2015 "On the features of introduction of the list of branches of study and specialties for the training of higher education applicants", a specialty 15.00.01 "Technology of drugs, organization of 
pharmaceutical business and forensic pharmacy" was renamed to specialty 226 "Pharmacy, Industrial Pharmacy" (branch of study 22 "Healthcare").

The new specialty was considered related to the specialty 15.00 .01 "Technology of drugs, organization of pharmaceutical business and forensic pharmacy". It was licensed in 2016 and implemented at the Department of Technology of Biologically Active Substances, Pharmacy and Biotechnology of Lviv Polytechnic National University for the training of HE applicants by the third (educational-and-scientific) cycle.

Admission for specialty 226 "Pharmacy" (since 2017 - "Pharmacy, Industrial Pharmacy" following amendments to the list of specialties) at the third (educational-and-scientific) cycle study is based on the diploma of HE by the chemical and pharmaceutical specialties and entrance exam results. Accordingly, since 2016, students' admission for the first and second cycles study was carried out by the specialty 226 "Pharmacy" (similarly, since 2017 - "Pharmacy, Industrial pharmacy"). Therefore, these prerequisites have allowed the Lviv Polytechnic National University to develop new EPPs and ESPs for all three cycles of HE and to take into account the expectations of employers.

Our research aimed to summarize the experience on revision the EPP and ESP for the specialty 226 "Pharmacy, Industrial Pharmacy" in Lviv Polytechnic National University and to make the comparative analysis of corresponding educational programs (EP) in Danylo Halytsky Lviv National Medical University concerning the teaching of the GPP complex, that provides formation of certain competencies of future specialists for pharmacy branch.

\section{The principles of creation of educational-and-professional programs and the system of learning outcomes assessment at the Lviv Polytechnic National University}

The unified List of the branch of study, elaborated in Ukraine in 2016, allowed combining the different Lists of branches of study and science. It was based on ISCED-2013 (International Standard Classification of Education) and necessitated the creation of new EPPs for specialties that previously had other names ${ }^{1}$. Such an approach to the implementation of international standards is justified since the classification of education based on ISCED is harmonized with the Standard Industrial Classification of All Economic Activities (SIC), which has become an important condition for

${ }^{1}$ ISCED Fields of Education and Training 2013 (ISCED-F 2013), UNESCO Institute for Statistics, Montreal. URL: http://www.uis.unesco.org/Education/Documents/iscedfields-of-education-training-2013.pdf 
appropriate training of specialists in relation to labor market needs. The National Standard Classification of Education ${ }^{2}$ is a tool for transparency of $\mathrm{HE}$ in Ukraine, which is towards integration into the European and international educational space.

The Law of Ukraine "On Higher Education"3 also provided for a change in the concept of the organization of education: from a teacher-oriented to a student-centered approach, from a process-centered to learning outcomes (LO) approach. It was necessary to standardize not the list of normative disciplines, but the list of graduate competencies and the normative content of training, which are defined as "learning outcomes"4. The reform in HE in Ukraine has led to the development of the student-centered learning conception aimed the forming a qualified competitive specialist, capable of the research-andinnovative type of thinking, who needs continuous professional development and has the appropriate skills. The student-centered approach requires direct, meaningful discussion between students, professors, and the administration of the HE institution regarding the design and organization of the training program. The program should provide students with an opportunity to choose courses, create individual educational paths, elective classes. Therefore, it is extremely important that this program should have a flexible structure. The flexible organization of learning, teaching and self-assessment activities, including schedule flexibility, are also important. It is necessary to introduce interactive learning systems into the educational process, to provide the participants of this process with the possibility of self-improvement, self-control of knowledge, independent work with educational materials in the mode and volume that satisfies them, as well as the choice of a rich information base, various ways of communication, including interactive, for solving educational problems and forming the specialists competencies ${ }^{5}$.

Implementation of the Law of Ukraine "On Higher Education" at Lviv Polytechnic National University is carrying out by the development and

2 Національна стандартна класифікація освіти. Національна академія педагогічних наук України. URL: http://naps.gov.ua/uploads/files/sod/NSKO.pdf

${ }^{3}$ Про вищу освіту: Закон України від 01.07.2014 р. № 1556-VII. Дата оновлення: 16.01.2020. URL: https://zakon.rada.gov.ua/laws/show/1556-18

${ }^{4}$ Koster A., Schalekamp T., Meijerman I. Implementation of Competency-Based Pharmacy Education (CBPE). Pharmacy. 2017. Vol. 5(1). 10-26. DOI 10.3390/ pharmacy5010010.

5 Zubin A. Competency and its many meanings. Pharmacy. 2019. Vol. 7(2). P. 37. DOI 10.3390/pharmacy7020037.

Parson L., Childs B., Elzie P. Using competency-based curriculum design to create a health professions education certificate program that meets the needs of students, administrators, faculty, and patients. Health Prof. Educ. 2018, Vol. 4, P. 207-217. DOI 10.1016/j.hpe.2018.03.008 
approval of internal standards for QA in education, including those concerning the Higher Education Standard (HES) - HES LP 02 "Studentcentered learning":

HES LP 02.01. Regulations on the organization of educational process at Lviv Polytechnic National University;

HES LP 02.02. Regulations on the organization of educational process for postgraduate $(\mathrm{PhD})$ students and for Doctor of Philosophy applicants beyond $\mathrm{PhD}$ studies at Lviv Polytechnic National University;

HES LP 02.03. Regulations on the academic mobility for applicants of bachelor, master, doctoral and postdoctoral studies and academic staff at the Lviv Polytechnic National University;

HES LP 02.04. Regulations on the organization of students' practical training (PT) at Lviv Polytechnic National University;

HES LP 02.05. Regulations on the organization of the courses teaching in foreign languages;

HES LP 02.06. Regulations on the organization and monitoring of students' independent extra-auditorium learning;

HES LP 02.07. The procedure of organization of study according to student's individual schedules;

HES LP 02.08. Regulations of the student's research work at the Lviv Polytechnic National University;

HES LP 02.09. Regulations on the provision of paid educational services of students learning certain disciplines and other components of the curriculum in excess of the syllabus established at the Lviv Polytechnic National University;

HES LP 02.10. Regulations on the organization of the Ukrainian student's Olympiads at the Lviv Polytechnic National University.

HRS LP 02.11. Regulations on the organization of the Ukrainian competition of the student's scientific projects according to the branch of study and specialties.

Consequently, student-centered learning involves educational methods that shift the focus of education from teacher to student. The principles of student-centered learning are as follows: 1) the teacher should not be a lecturer, but a facilitator of the learning process; 2) he/she provides successful group communication; 3) not so many lectures, but more research, discussions, and projects; 4) application of flip learning, problembased learning; 5) clickers. The tasks of the EPP/ ESP development team consisted not only creation of training programs, but also solving the following questions: 1) introduction of student-centered learning practices into the educational process; involvement of employers in the development of educational programs (EP); 2) student's participation in the training programs formation; 3) student's choice of subjects; 4) implementation of contemporary quality assurance (QA) practices into the activities of Lviv Polytechnic National University. 
Environmental, Social, and Governance (ESG) criteria as QA standards and recommendations in the European Higher Education Area (EHEA) ${ }^{6}$ according to the European Association for Quality Assurance in Higher Education (ENQA) provides for student-centered learning and teaching: 1) respect and attention to the diversity of students and their needs, making it possible flexible learning trajectories; 2) the application of different appropriate ways of material's presentation; 3) flexible use of various pedagogical methods; 4) regular evaluation and correction of material supply and pedagogical methods; 5) encouraging students' independence while providing proper mentoring and support from the teacher; 6) developing mutual respect in the relationship between the student and the teacher; 7) proper response to student complaints. Also, teachers should be aware of the available methods of examination and control of knowledge and must receive support in developing their skills in a certain area. Assessment methods, as well as evaluation criteria, should be notified previously. The assessment allows students to demonstrate the level of achievement of the intended LO. Students receive feedback, accompanied, when necessary, with advice on the learning process. If it is possible, more than one examiner measures student learning. The rules of assessment of LO should provide an opportunity to take into account mitigating circumstances. The assessment is applied consistently and fairly to all students and is conducted according to established procedures. There is a formal procedure for student appeals.

An internal system for assessing the quality of education is being formed at the Lviv Polytechnic National University. Student-centered learning is the main element of this system. For example, the involvement of students in the process of QA in an educational system is a fundamental principle of the regulation, and its purpose is an ensuring the requirements and expectations of the educational service seekers (entrants, students, $\mathrm{PhD}$ students). Particular attention is paid to the introduction of student-friendly forms and methods of learning, interactivity, mobility and mentoring.

The possibility of identification, quantification, and measuring are important for LO estimation.

The development of EP and systems for LO estimation can be represented as an informational outline of the relationship between elements of the HE system. The informational outline (Fig. 1) can be viewed from different perspectives: as an elements of the websites of HE establishments, including the electronic office of the HE seeker; as an opportunity for the employer to get acquainted with EPP/ESP, syllabus on disciplines, the system of LO assessment and to influence them in a certain way.

${ }^{6}$ Standards and guidelines for quality assurance in the European Higher Education Area (ESG). Brussels, Belgium: European Association of Institutions in Higher Education. 2015. 27 p. URL: https://enqa.eu/index.php/home/esg/ 


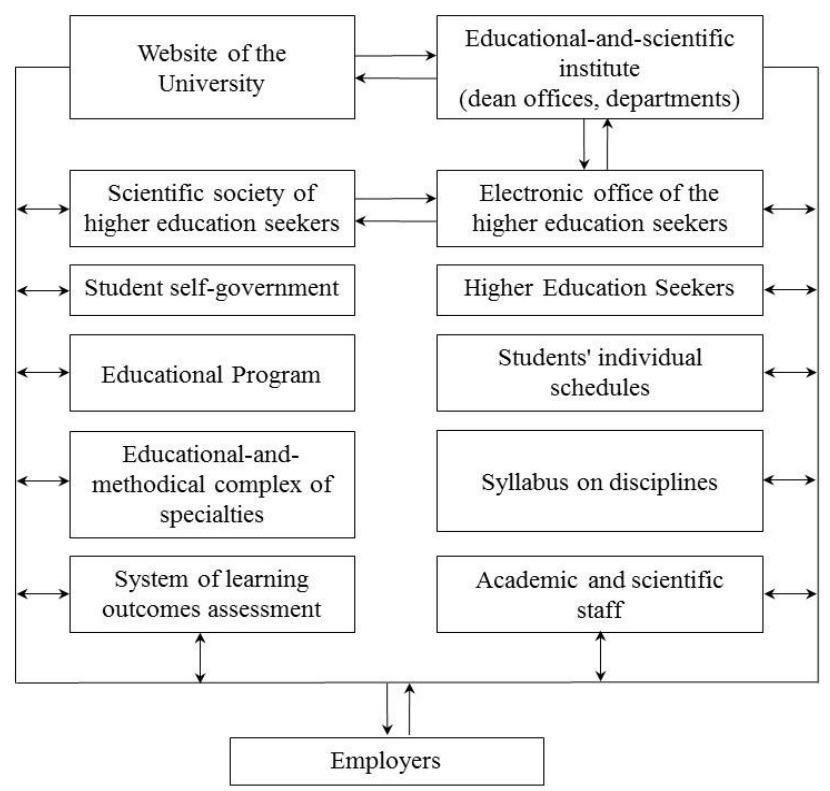

Fig. 1. Information outline of the relationship between the elements of the system of creation of educational-and-professional programs and the system of LO assessment

Also, the procedures for creating students' individual schedules, as well as the possibility of communication between HE seekers within their own partnership and student self-government are clear and transparent.

\section{Elaboration of the structural-and-logical framework and defining competencies for disciplines at the first cycle study (bachelor program) at Lviv Polytechnic National University}

Structural-and-logical framework of bachelor training (the first educational-and-qualification cycle) for specialty 226 "Pharmacy, Industrial Pharmacy" contains 2 selective blocks: "Pharmacy" and "Technologies of pharmaceutical preparations" (Fir. 2-3).

The 2 specializations - 226.1. "Pharmacy" and 226.2. "Industrial Pharmacy" within specialty 226 "Pharmacy, Industrial Pharmacy" have proposed at a meeting of the Scientific-and-methodological commission of the Ministry of Education and Science of Ukraine. Consequently, developed selective blocks are relevant.

We have selected competencies that are formed by the appropriate disciplines (table 1). 

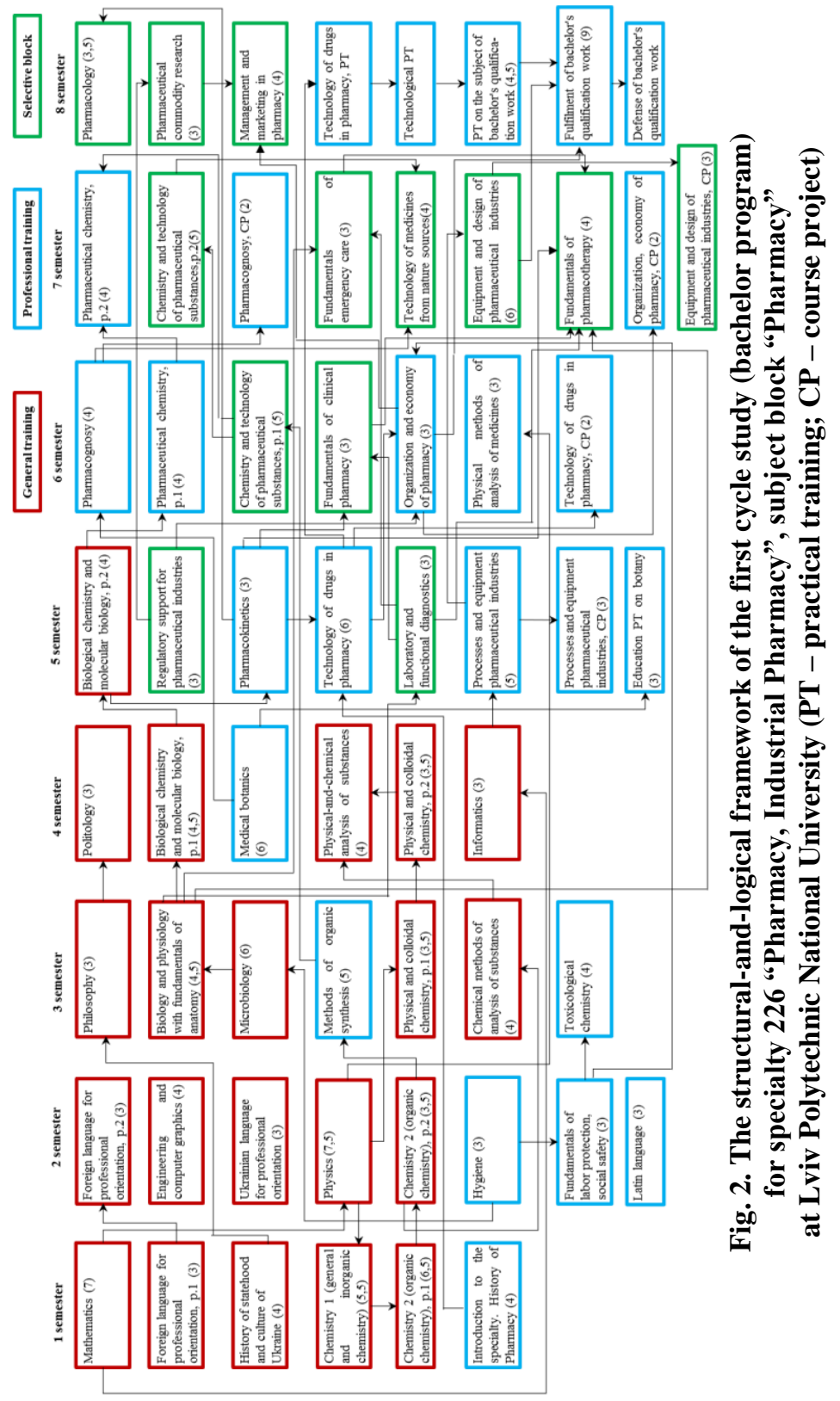

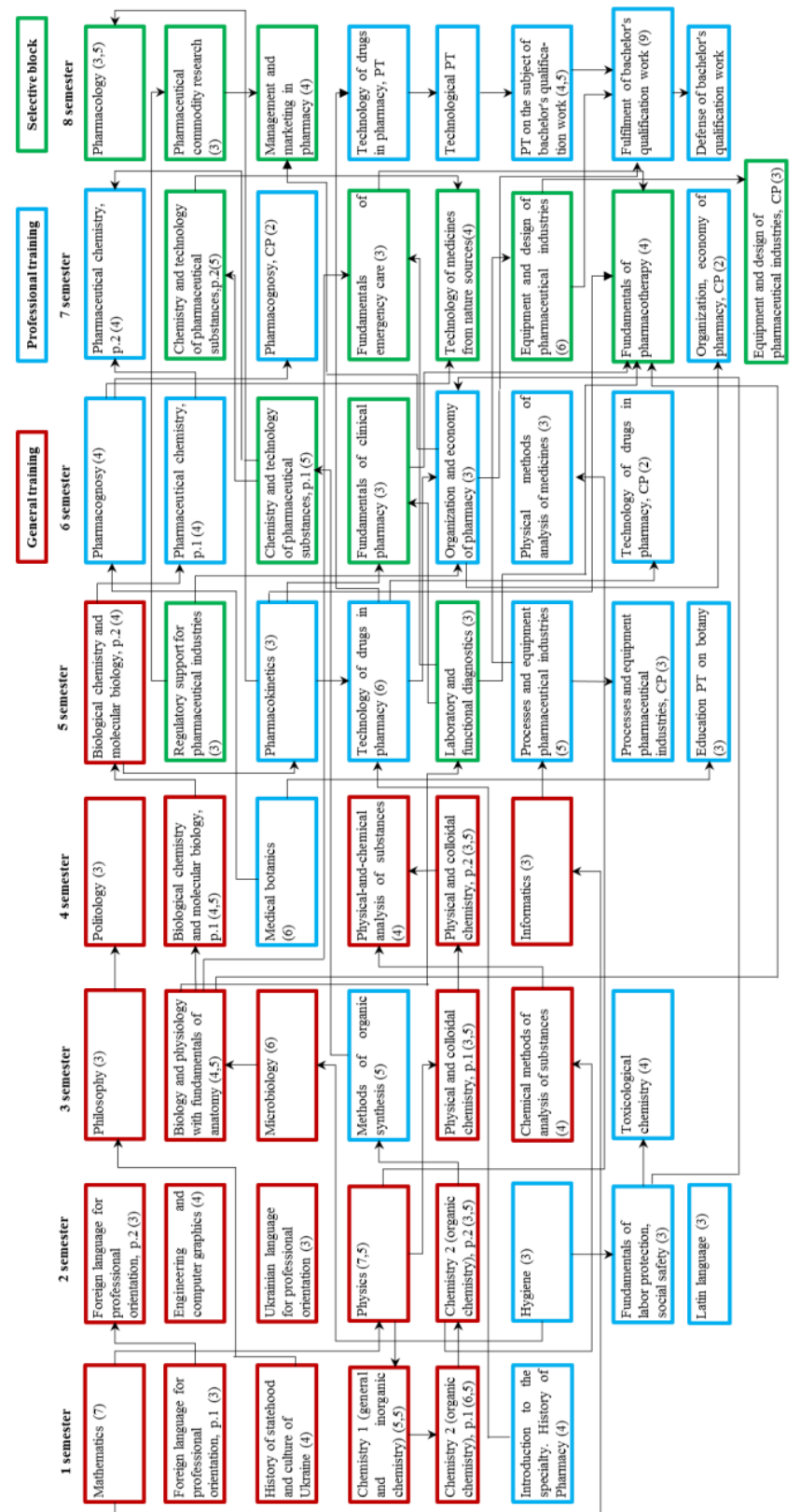

สั 荬

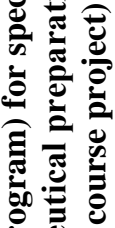
릉 党告 氙

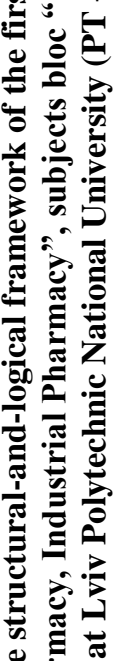
ल 这 


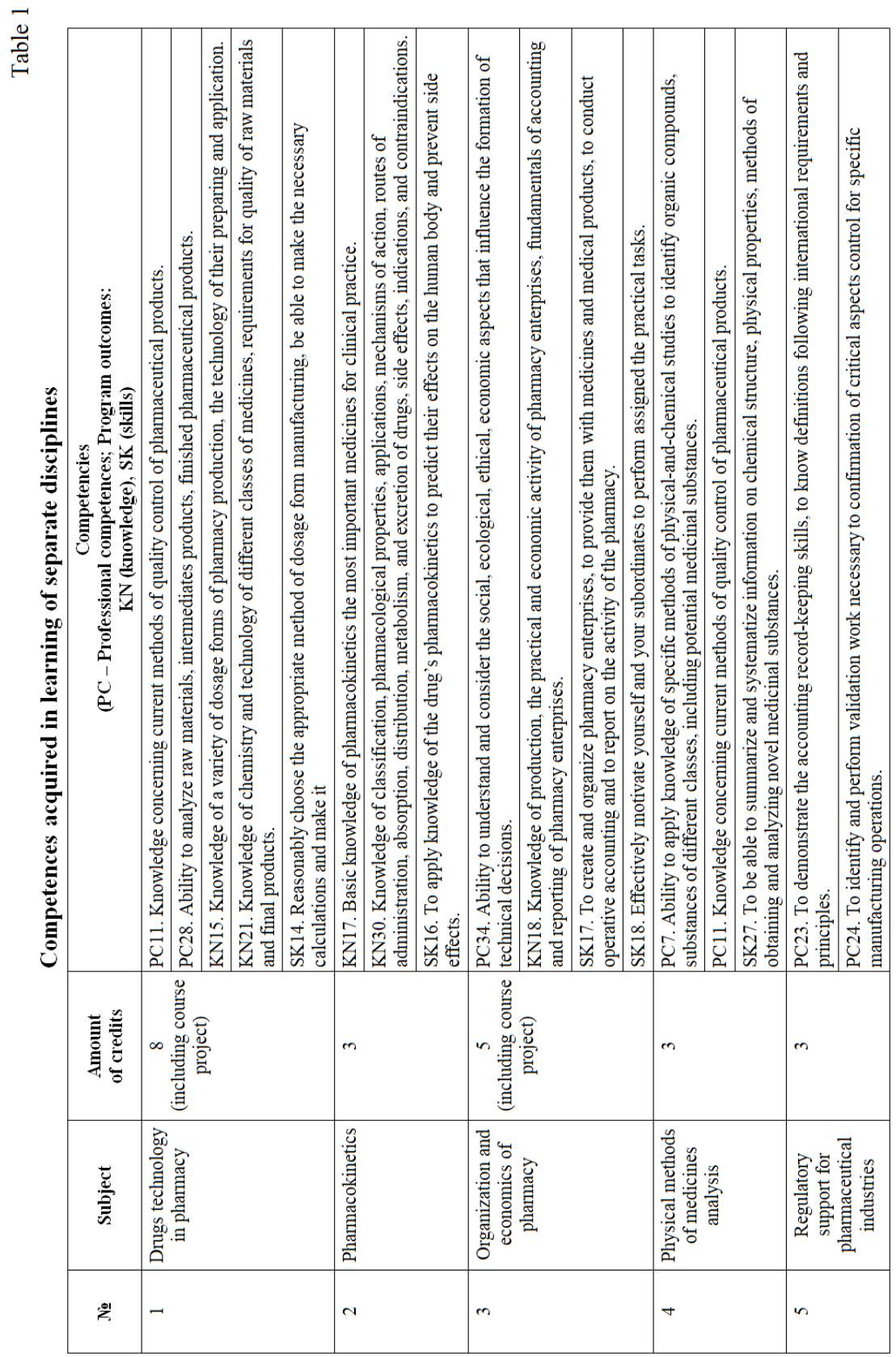




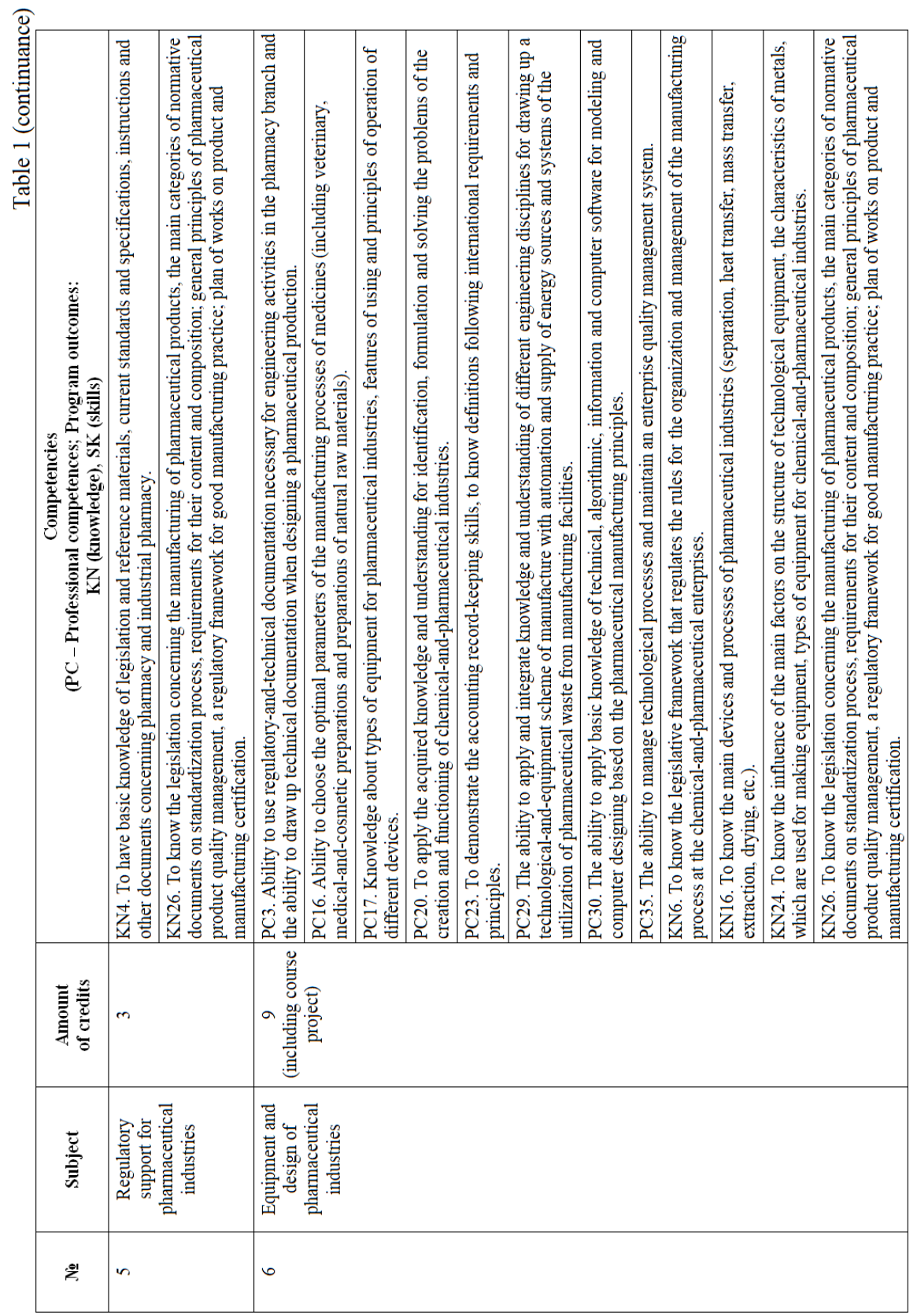




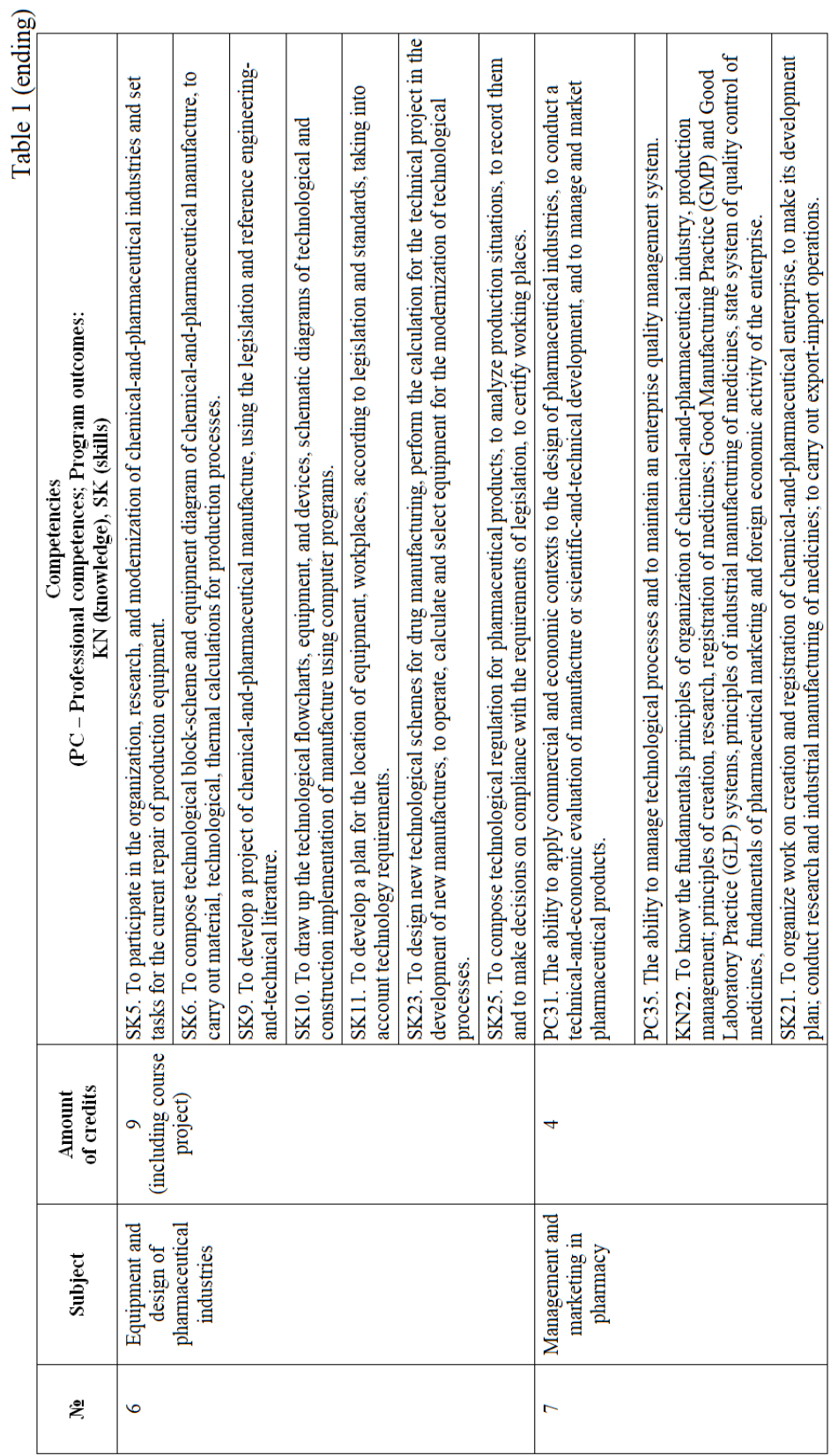


An analysis of the content of the EPP by component groups and training cycles was also conducted (table 2).

Table 2

The division of EPP by component groups and training cycles

\begin{tabular}{|c|c|c|c|c|}
\hline \multirow[b]{2}{*}{ № } & \multirow{2}{*}{$\begin{array}{l}\text { Cycle } \\
\text { training }\end{array}$} & \multicolumn{3}{|c|}{$\begin{array}{l}\text { The volume of academic load for HE applicants } \\
\text { (credits /\%) }\end{array}$} \\
\hline & & $\begin{array}{c}\text { Mandatory components } \\
\text { of EPP }\end{array}$ & $\begin{array}{c}\text { Selective } \\
\text { components of } \\
\text { EPP }\end{array}$ & Total \\
\hline 1 & $\begin{array}{l}\text { General } \\
\text { training cycle }\end{array}$ & $90 / 38$ & $12 / 5$ & $102 / 43$ \\
\hline 2 & $\begin{array}{l}\text { Professional } \\
\text { training cycle }\end{array}$ & $88,5 / 37$ & $49,5 / 20$ & $138 / 57$ \\
\hline \multicolumn{2}{|c|}{ Total } & $178,5 / 75$ & $61,5 / 25$ & $240 / 100$ \\
\hline
\end{tabular}

\section{Elaboration of the structural-and-logical framework and defining} competencies for disciplines at the second cycle study (master program) at Lviv Polytechnic National University

The training of masters and master of research is carried out for organizational-and-managerial, investment and scientific-and-research activity, for training of teaching and scientific reserve of HE establishments, research institutions in the pharmacy and industrial pharmacy branch, as well as for the manufacture of medicines, their storage, quality control, delivery, distribution, regulation of drug supply, as well as advice, provision of information on medicinal products.

Structural-and-logical framework of master training (the second educational-and-qualification cycle) for specialty 226 "Pharmacy, Industrial Pharmacy" contains 2 selective blocks: "Pharmacy" and "Technologies of pharmaceutical preparations" (Fir. 4-7).

The courses provide the students' competences according to the requirements of the HE standard (table 3 ).

The results of analysis of the content of the EPP by component groups and training cycles are presented in table 4 . 


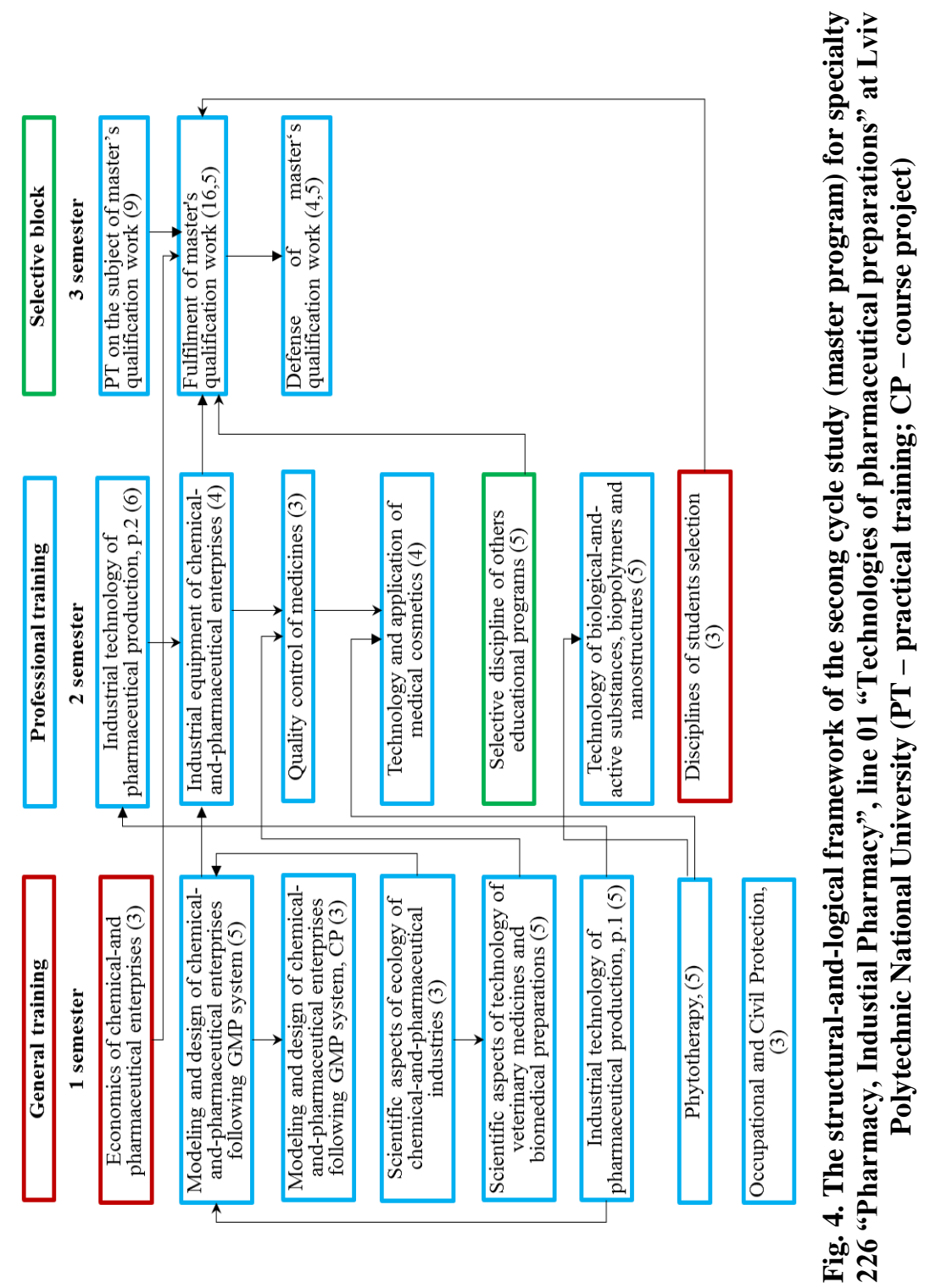




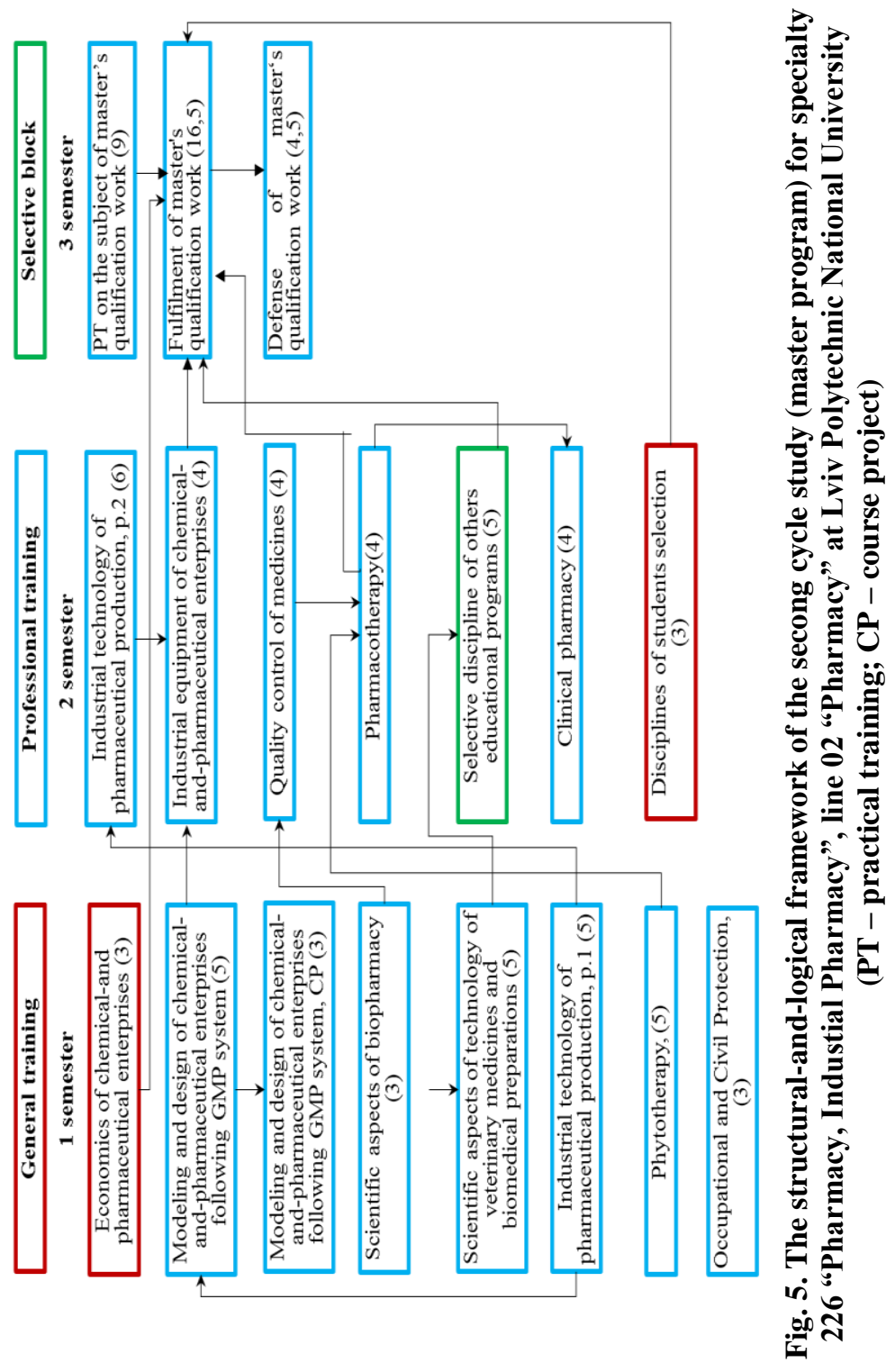



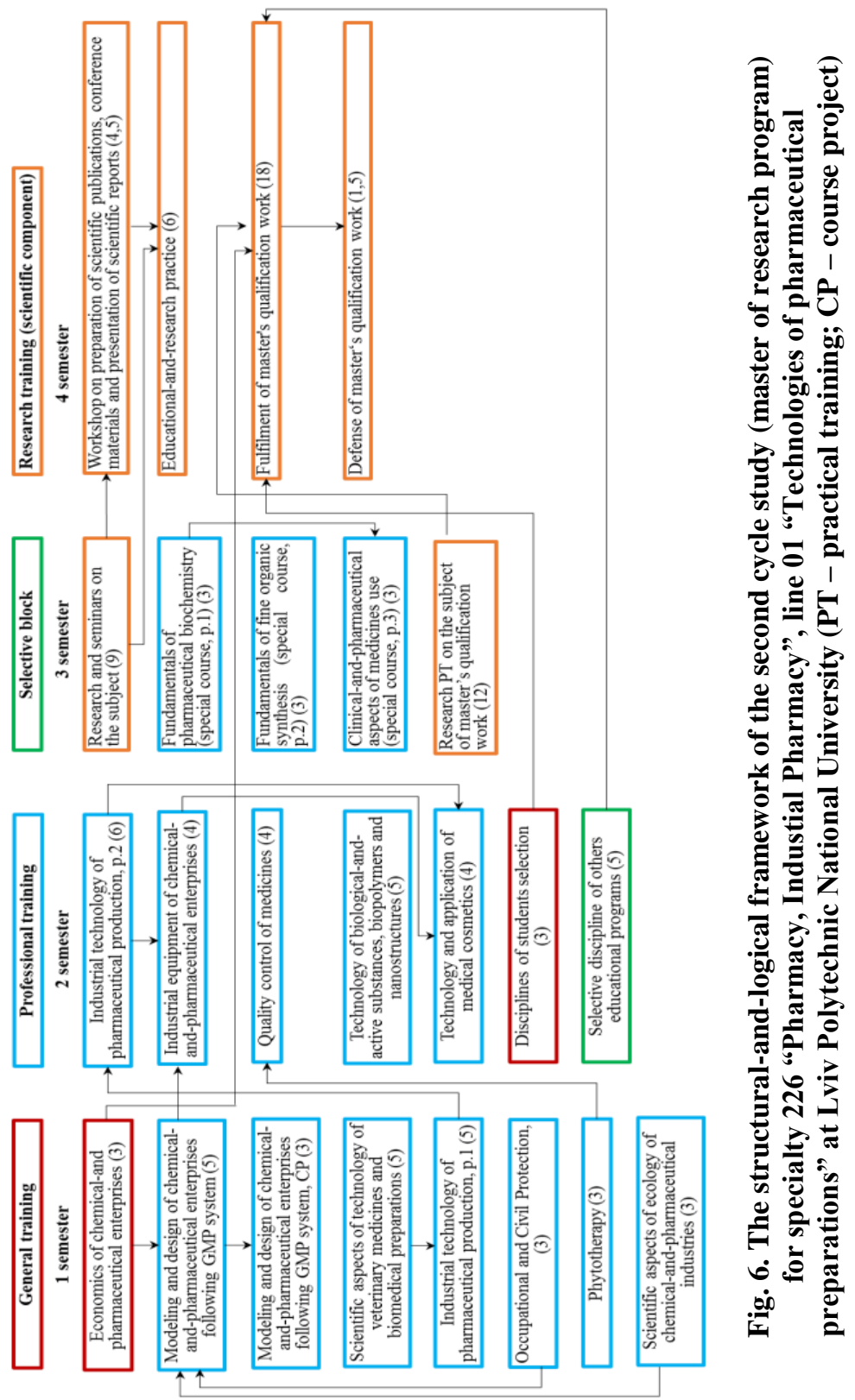


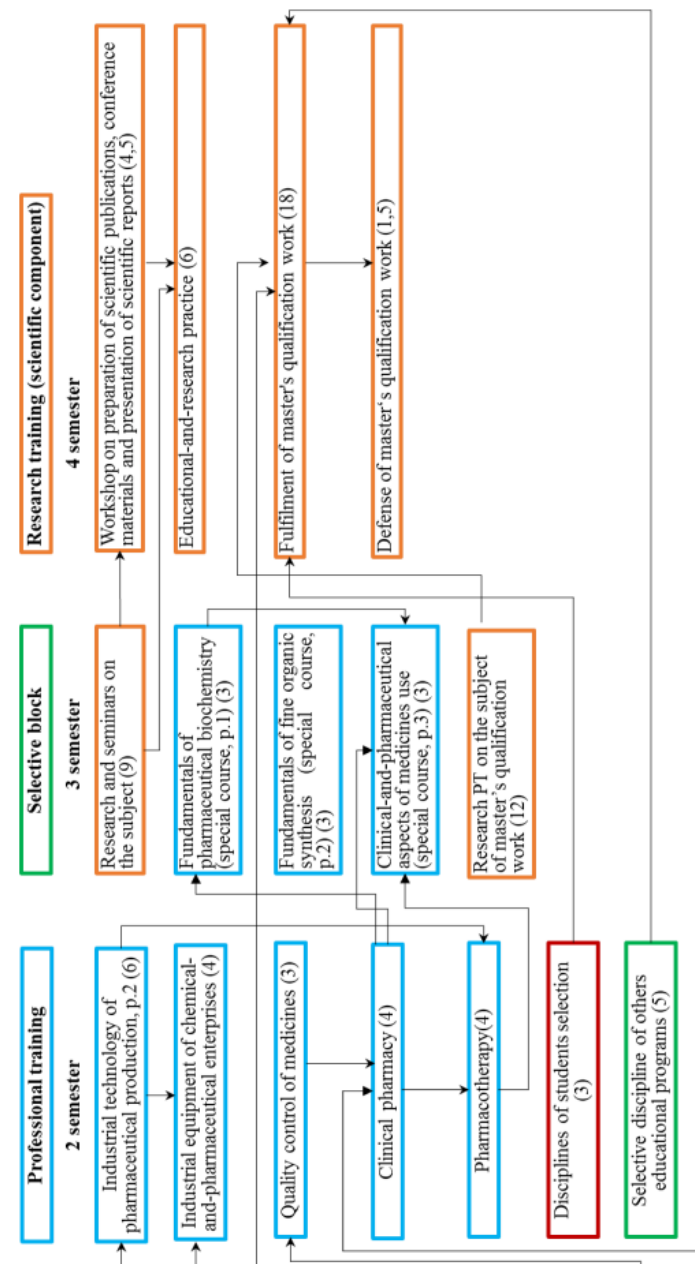

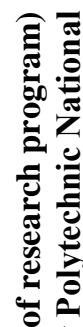

离爷

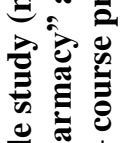

है है

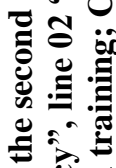

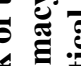

ํㅡㄹ

츨

흘 을

.

흘 힐

틀

竭
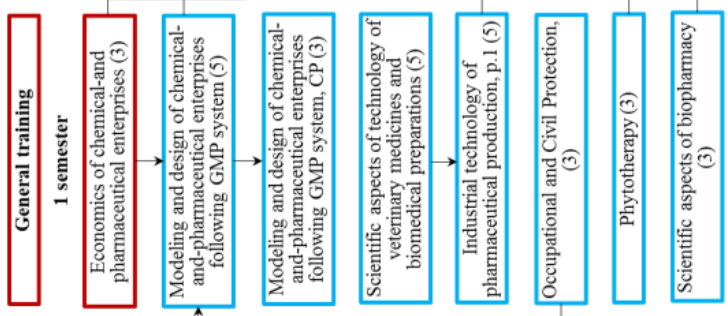

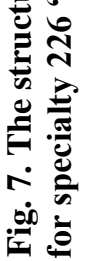




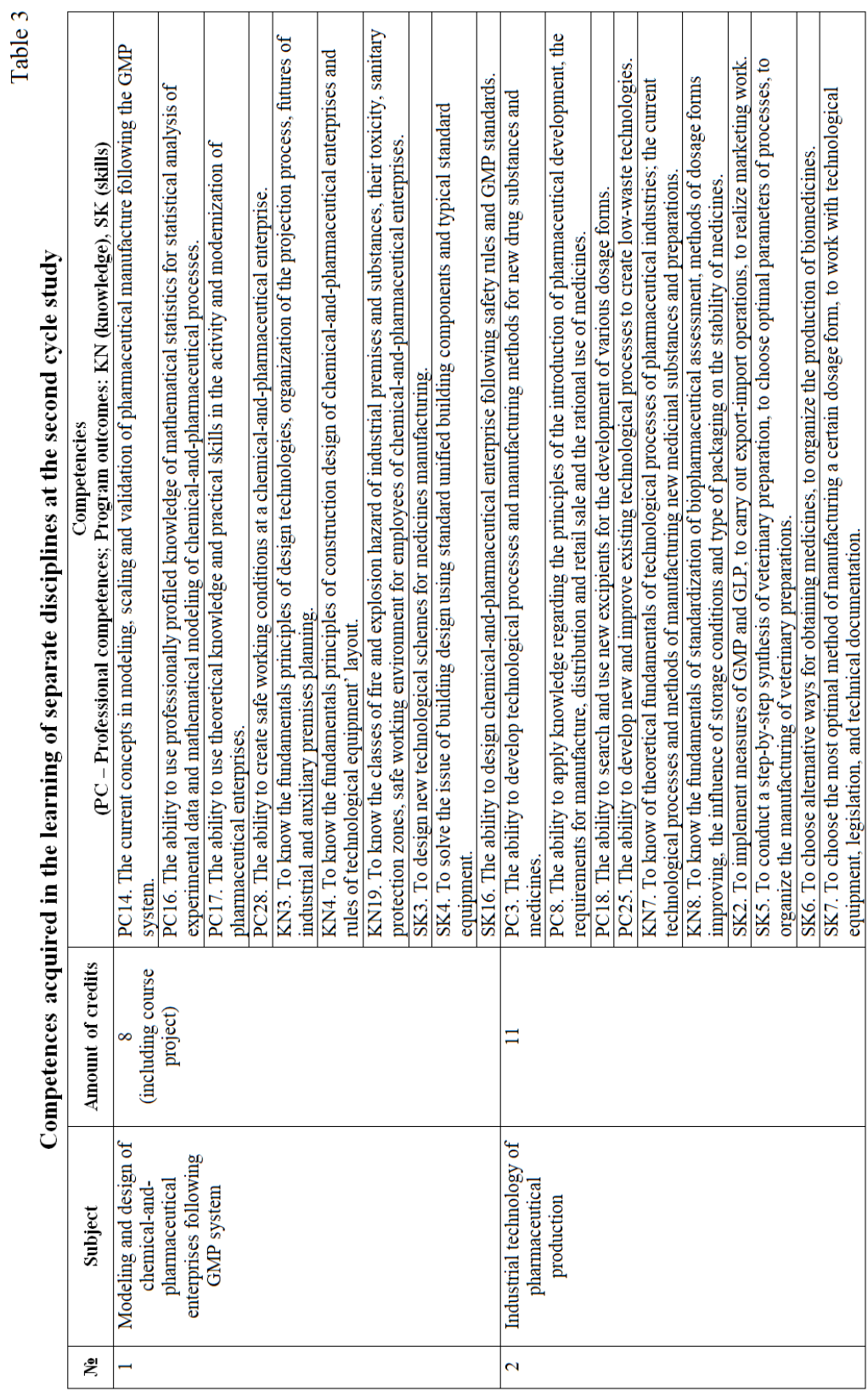



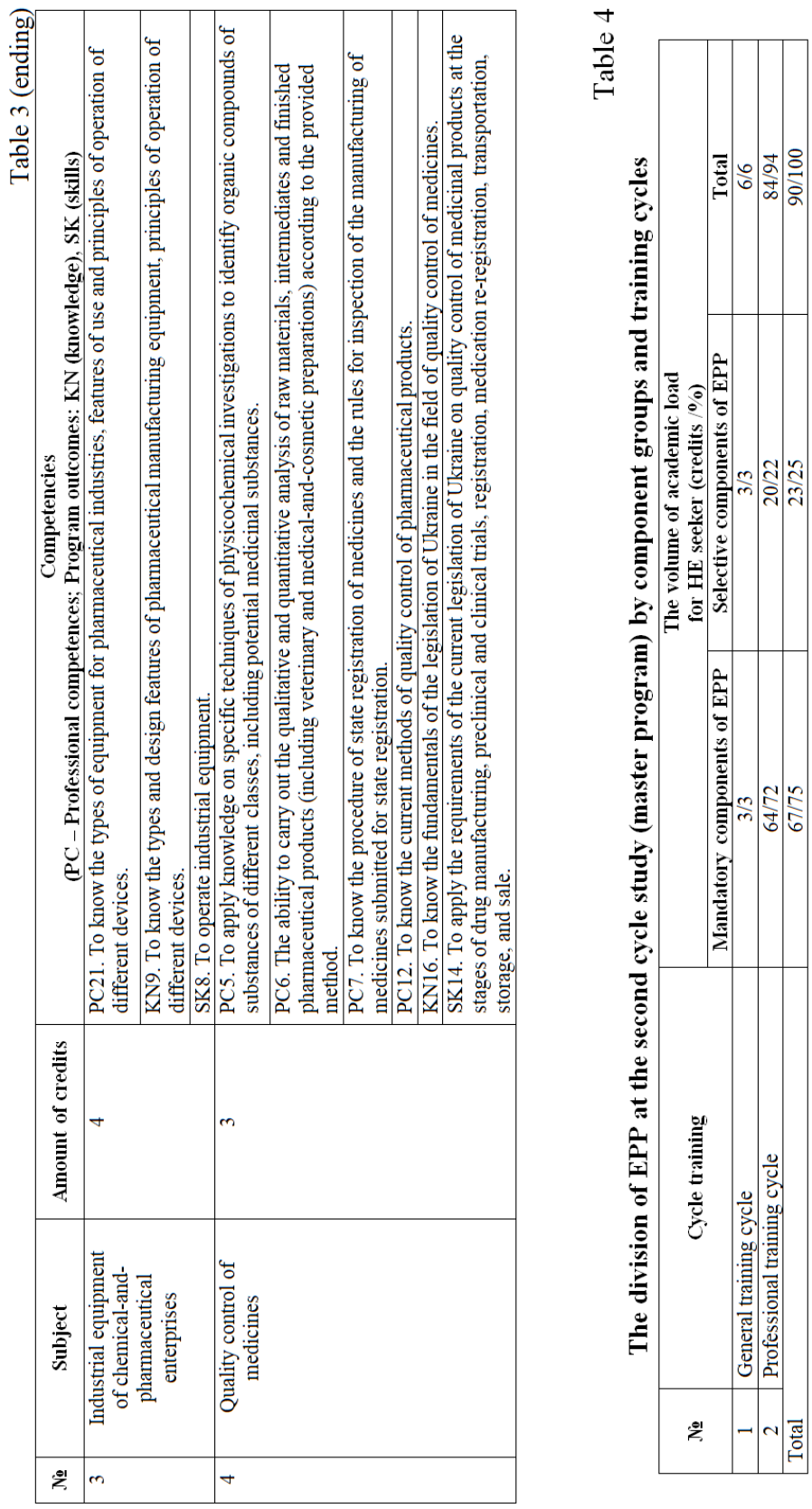


\section{Elaboration of the structural-and-logical framework and defining competencies for disciplines at the third cycle study (doctoral program) at Lviv Polytechnic National University}

At the 2003 conference in Berlin, for the first time, doctoral studies and synergies between the EHEA and the European Research Area (ERA) have been discussed. Whereas the Bologna Declaration referred to two cycles which include all programs of tertiary education ("The second cycle should lead to the master and/or doctorate degree as in many European countries"), the 2003 Berlin Ministerial Communiqué consequently defined doctoral programs as the third cycle.

The third cycle study at Lviv Polytechnic National University includes a broad variety of doctoral phases from pure (doctoral) study programs to fully independent research. These models have various implications for:

- the structure of doctoral studies (free, partially or fully structured);

- the responsibility is taken and the resources invested (e.g. staff and facilities for taught parts of the program) by the home institution;

- possible links with enterprises and/or professional bodies;

- the relation of mandatory and optional elements for the doctoral student;

- the status of the doctoral candidate (student, employee, researcher).

At Lviv Polytechnic National University, the individuals carrying out these projects are not regarded as students but as early-stage researchers/young professionals.

Structural-and-logical framework of philosophy doctor training (the third educational-and-qualification cycle) for specialty 226 "Pharmacy, Industrial Pharmacy" is presented in Fig. 8.

The main competencies that are formed by the appropriate disciplines are presented in table 5.

An analysis of the content of the EPP for the third cycle study by component groups and training cycles was conducted (table 6).

Modernization of professional training through international cooperation and recognition of certificates and assessment of acquired competencies has great importance ${ }^{7}$.

In the period 2016-2020, Lviv Polytechnic National University was a partner of the current agreement with Le Mans University (Le Mans, France) about the double diploma. The travel for students training in master's programs, for $\mathrm{PhD}$ students to conduct the research and for teachers to give lectures and passing the training was organized within the framework of the signed agreements on international academic mobility according to the Erasmus + KA1 program with the Lviv Polytechnic National University and the University of Le Mans (Le Mans, France), the University of Opole (Opole, Poland), the University of Toulouse III Paul Sabatier (Toulouse, France), Isa Lille (Lille, France).

${ }^{7}$ Pearson, M, Hubball, H. Curricular Integration in Pharmacy Education. American Journal of Pharmacy Education. 2012. Vol. 76. P. 204-220. DOI 10.5688/ajpe7610204. 


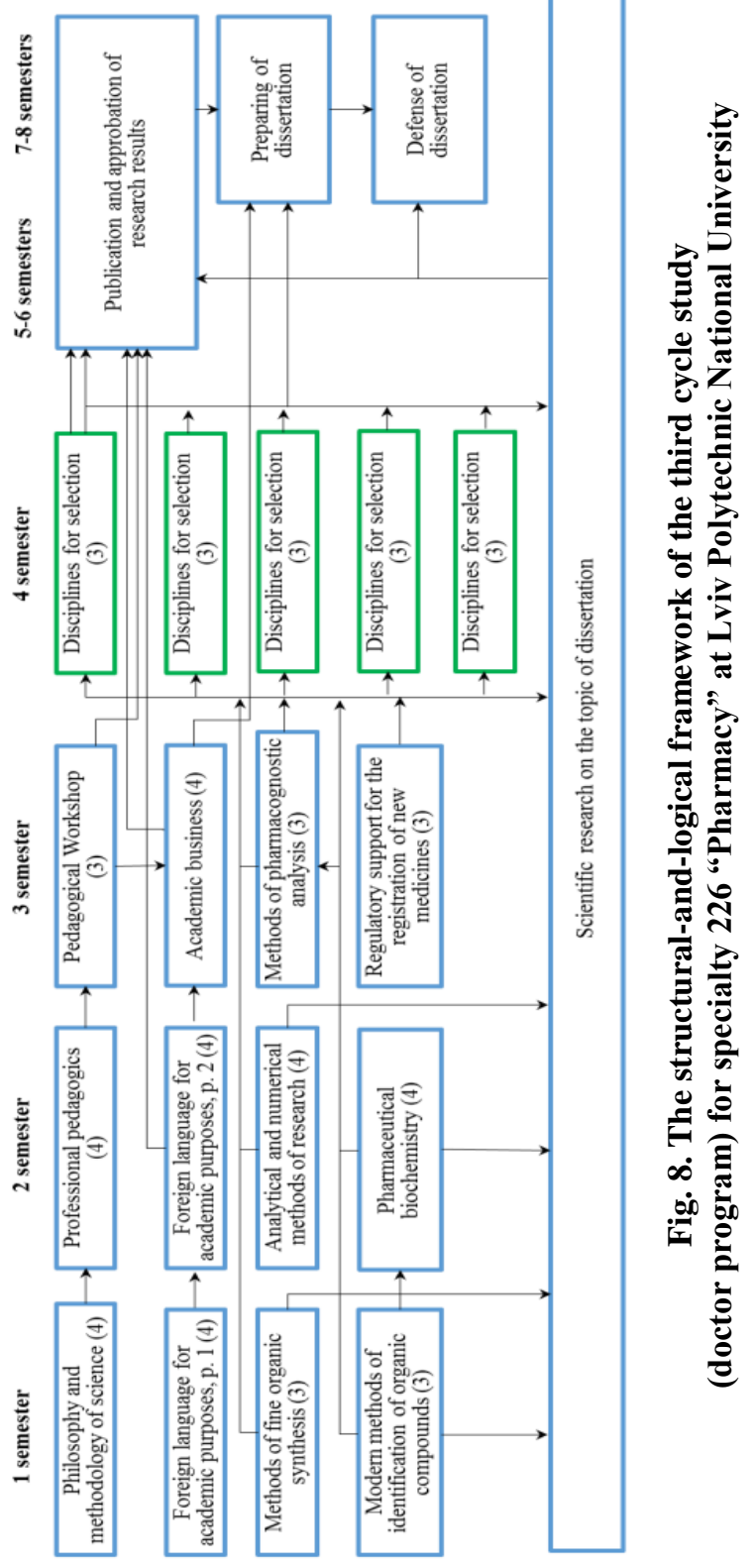




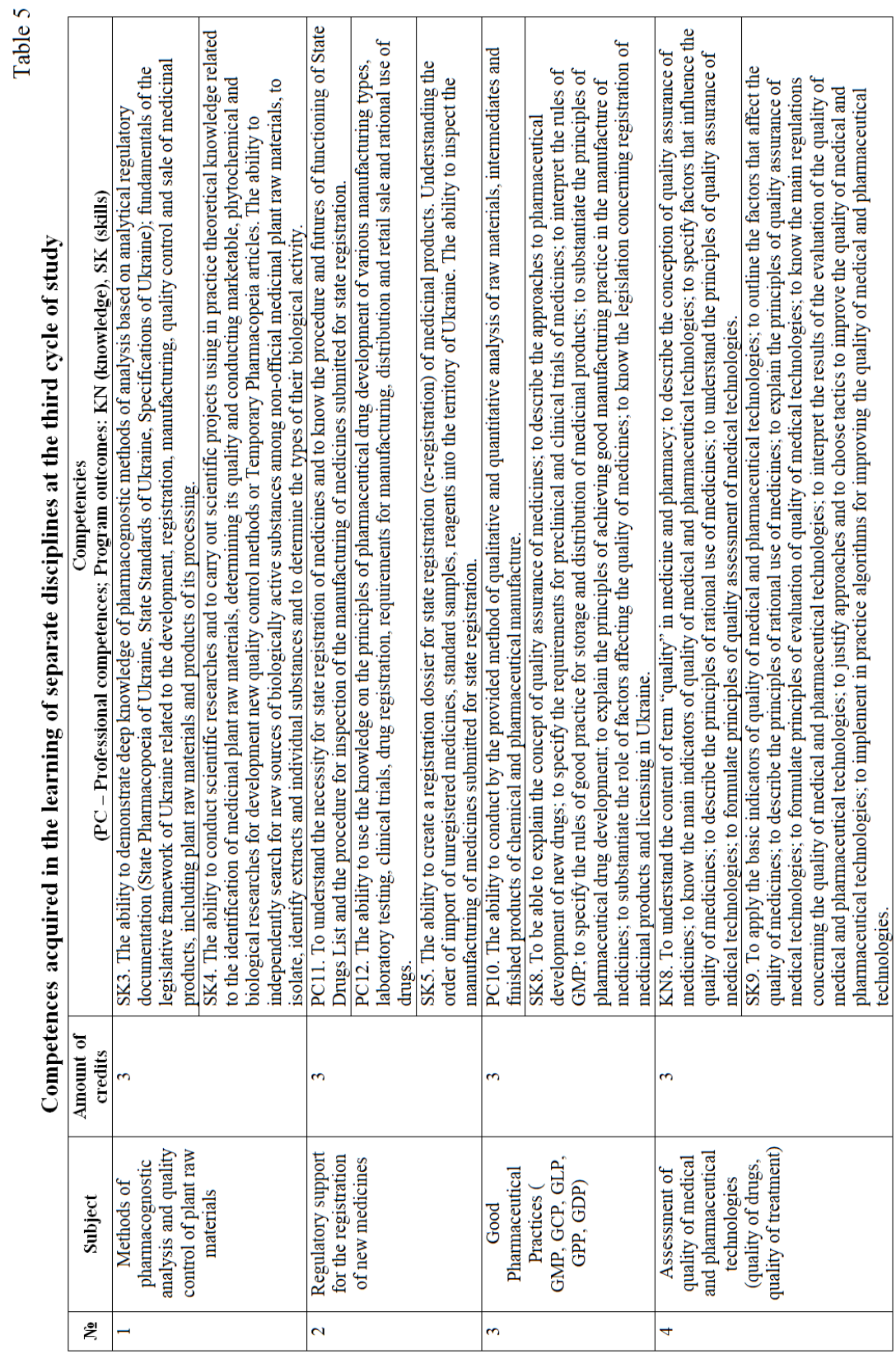


年

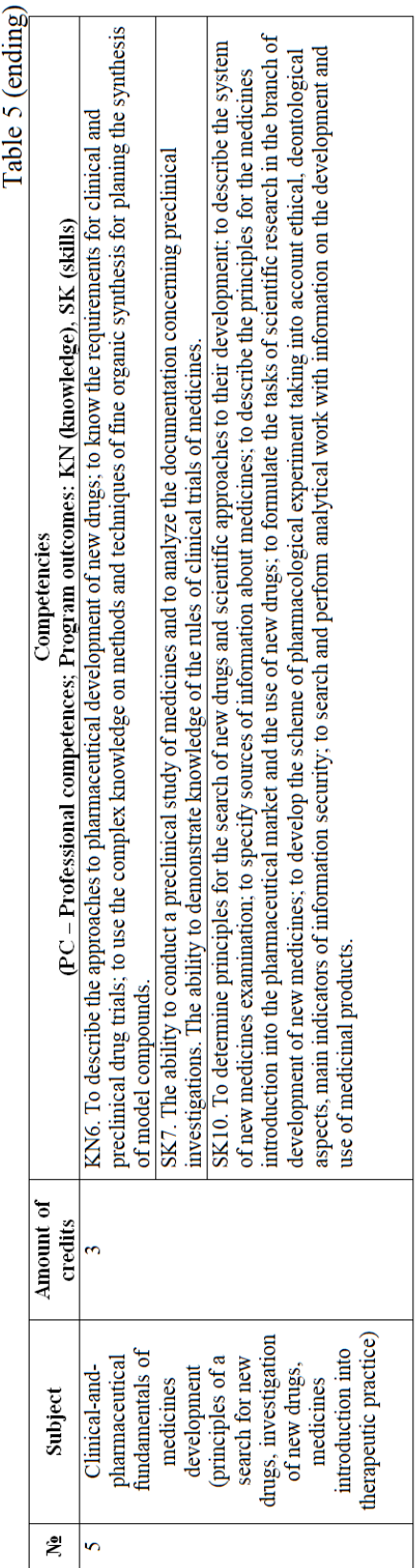

苞

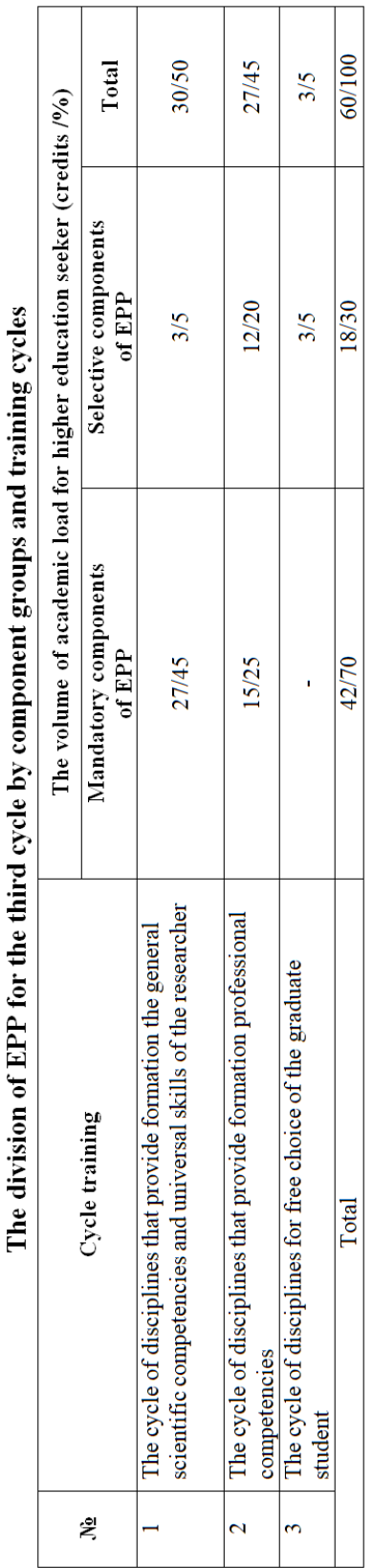


Also, at the same period, Lviv Polytechnic National University was a partner of projects of international bilateral scientific and technical cooperation: Ukraine-France M/85-2017, M/113-2018 "Creating sulfurcontaining derivatives of carbocyclic and heterocyclic systems - potential antithrombotic substances" (2017-2018); Ukraine-Poland M/120-2018, M/42-2019 "Derivatives of 9,10-anthraquinone and related carbo- and heterocyclic systems as prototypes for potential antitumor and antifungal substances" (2018-2019). As part of the cooperation agreement between the Lviv Polytechnic National University and the University of Opole (Opole, Poland), training for teachers was organized.

Thus, the analysis of particular directions of work in the process of training specialists for the pharmacy branch shows the important role of services of international cooperation, their direct and tangible influence on the process of formation of a competitive specialist. Internships, practices abroad, other types of academic exchanges contribute to the improvement of competency qualities, tempering of character, personality development of a specialist at different cycles of study ${ }^{8}$.

\section{The peculiarities of formation of professional competencies on Good Pharmaceutical Practices in the training of specialists at Danylo Halytsky Lviv National Medical University}

The development and implementation of GPP standards in the healthcare establishments' activities should be a logical continuation of the strategy of implementation of the Good Practices System in our country, which guarantees the quality of medicines at all stages of their circulation from manufacture to sale for the end consumer. The most important requirement for pharmacy professionals involves the support and continuous improvement of their professional activity ${ }^{9}$.

An analysis of the syllabuses of the disciplines, learned by HE seekers in second (master program) and third (doctoral program) cycles study at Danylo Halytsky Lviv National Medical University concerning mastering the future specialists expertise in GPP competencies has demonstrated some problematic issues and unresolved tasks.

At the Danylo Halytsky Lviv National Medical University, the core element of doctoral studies in almost all disciplines for a lot of years was

${ }^{8}$ Pittenger, A, Chapman, S, Frail, C, Moon, J, Undeberg, M, Orzoff, J. Entrustable Professional Activities for Pharmacy Practice. American Journal of Pharmaceutical Education. 2016. Vol. 80. P. 57-65. DOI :10.5688/ajpe80457.

${ }^{9}$ Гала Л.О. Постійний професійний розвиток фармацевтичних працівників вимога належної аптечної практики. Управління та економіка в фармації. 2016. № 3 (47). C. 24-30. 
self-contained research including a scientific dissertation. However, with influences from overseas, a range of innovative doctoral programs have been emerging in response to the changes in society and the challenges of a global labor market.

But, there are no separate disciplines on GPP for HE seekers at the second and third cycles of study. Some competences concerning GPP students acquired at the second (master program) cycle study, when learned disciplines such as "Technology of drugs", "Clinical pharmacy and pharmaceutical care", "Management and marketing in pharmacy", "Organization and economy of pharmacy", "Medicinal Plants Resources Science", "Standardization of medicines" (table 7).

The third (doctoral program) cycle study includes courses, private study, research and writing a thesis. This approach requires a great deal of autonomy and responsibility.

The HE seeker at the third (doctoral program) cycle should: 1) demonstrate knowledge and understanding in the field of research including current specialist knowledge in a limited area of this field as well as specialized knowledge of research methodology in general and the methods of the specific field of research in particular; 2) demonstrate the ability to identify and formulate issues with scholarly precision critically, autonomously and creatively, and to plan and use appropriate methods to undertake a limited piece of research and other qualified tasks within predetermined time frames in order to contribute to the formation of knowledge as well as to evaluate this work; 3) demonstrate the ability in both national and international contexts to present and discuss research and research findings in speech and writing and in dialogue with the academic community and society in general; 4) demonstrate the skills required to participate autonomously in research and development work and to work autonomously in some other qualified capacity.

Accordingly, there are no specific disciplines that are related to the principles of GPP at the third cycle study. Only a few issues of GMP are discussed in elective courses "Technological aspects of pharmaceutical development".

\section{CONCLUSIONS}

The scientific analysis of the state of the problem of the professional training of pharmaceutical branch specialists in terms of GPP at the technical and medical institution on the example of Lviv Polytechnic National University and Danylo Halytsky Lviv National Medical University is carried out. 


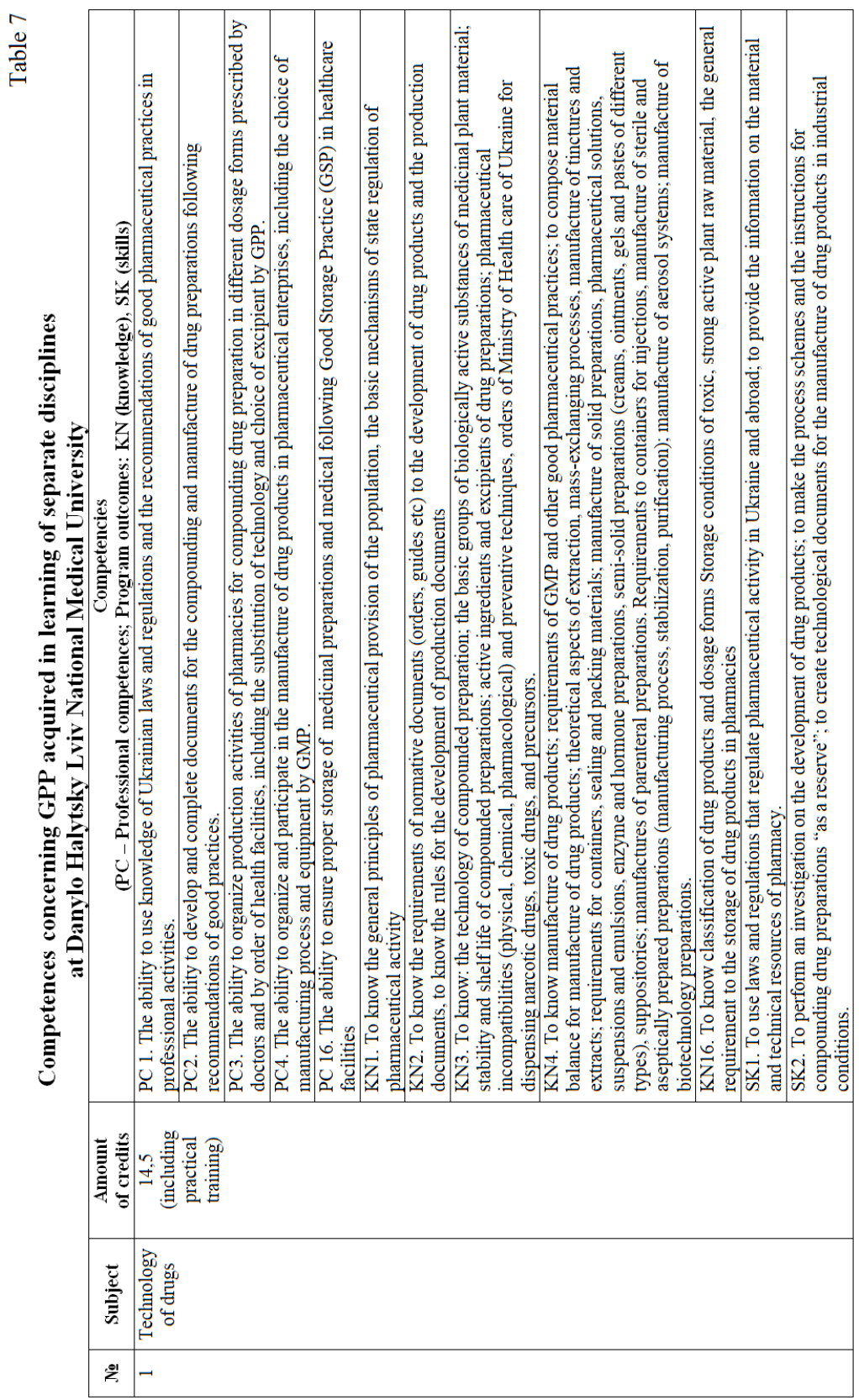




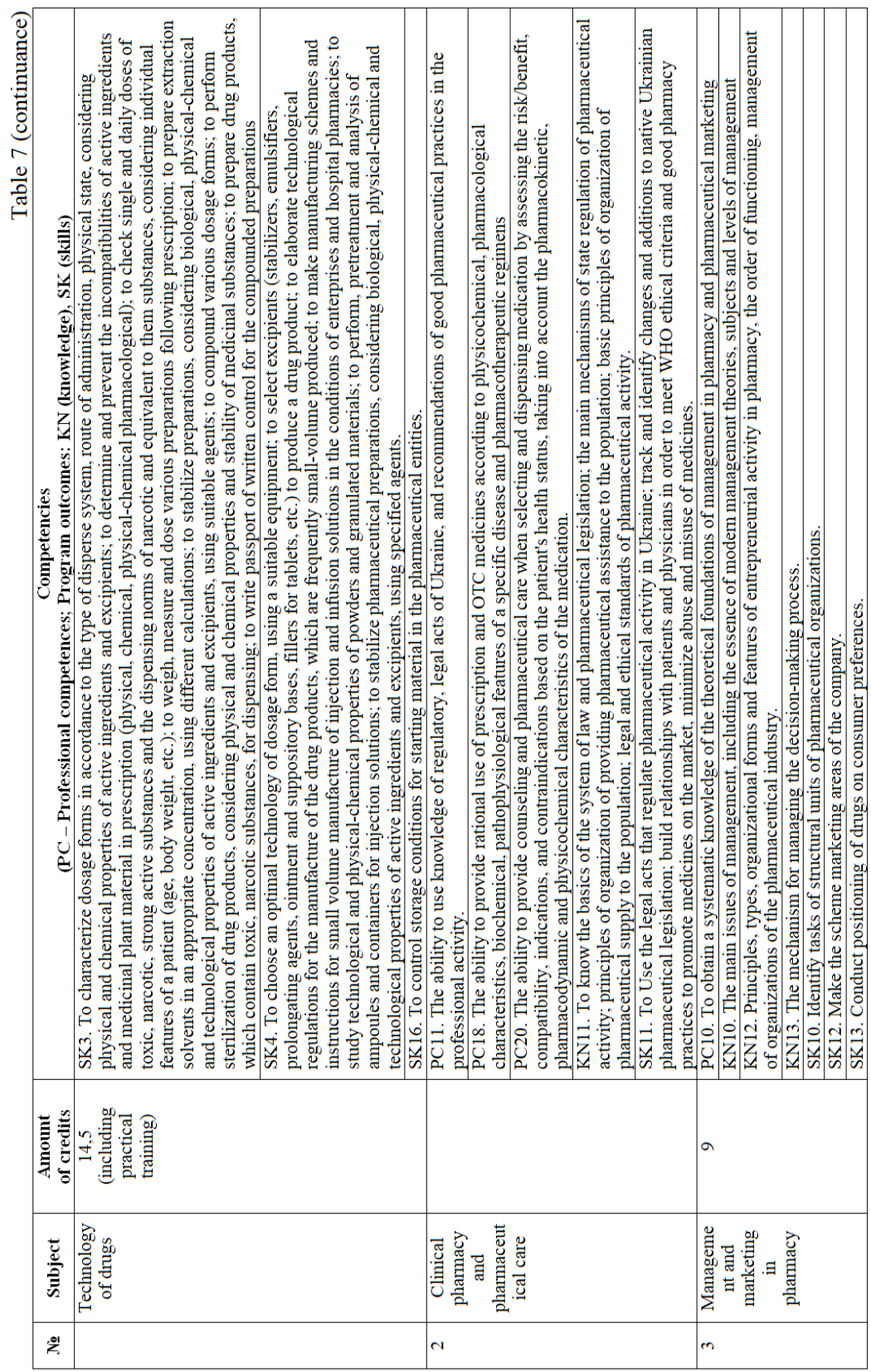




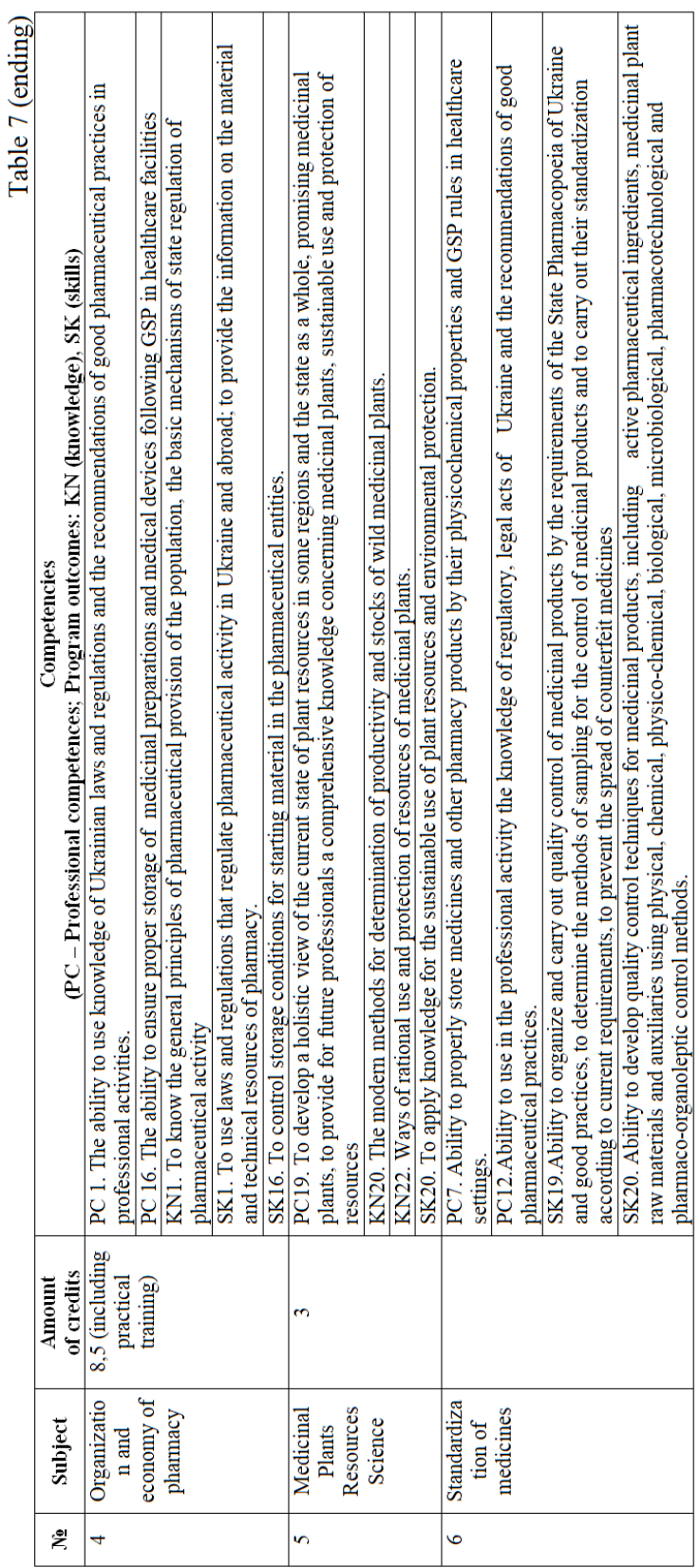


Certain individuality of professional training of specialists in the pharmaceutical industry in the context of the acquirement of professional competencies in GPP based on the analysis of the EPP and ESP was disclosed.

EPP for first (bachelor program) cycle study at Lviv Polytechnic National University consists of 14 general competencies, 35 professional competencies, 62 pieces of knowledges and skills. EPP for second (master program) cycle study involves mastering with 15 general competencies, 28 professional competencies, and 35 pieces of knowledges and skills. 16 general competencies, 8 professional competencies, 20 pieces of knowledges and skills comprise ESP for third (doctoral program) cycle study at Lviv Polytechnic National University. Almost all competencies related to GPP issues.

The logical conclusion of the training of specialists in the field of pharmacy is the discipline "Good Pharmaceutical Practices", which includes the whole range of practices, so it is proposed at the Lviv Polytechnic National University for study at the third (educational-scientific) level.

Unlike Lviv Polytechnic National University, HE seekers at Danylo Halytsky Lviv National Medical University study principles of GPP only at the second (master program) cycle study.

\section{SUMMARY}

As the complexity of the pharmaceutical industry increases a there is an increasing need for suitably qualified personnel. Universities must respond to needs for employers and graduates with the appropriate skills and knowledge to enable the transformation and future growth of this industry. Restructuring educational offerings to focus on graduate attributes, such as analytical and critical thinking, collaboration and problem-solving, creativity, flexibility and self-direction in the context of the pharmaceutical industry facilitates the changes needed for future growth and to the improvement of the pharmacy industry as a whole.

The aim of this article is to provide an overview of the applications of competency based education in the education and training of pharmacists, the process for constructing a competency based pharmacy curriculum, and the potential advantages and challenges associated with its implementation. The formation of competencies of future professionals for the pharmaceutical field, taking into account the relevance and expectations of potential employers, is an important component in the development of educational-and-professional and educational-and-scientific programs at all cycles (bachelor, master and doctoral programs) of higher education. The article present the result of scientific analysis of the state of the problem of 
the professional training of pharmaceutical branch specialists in terms of Good Pharmaceutical Practices at the technical and medical educational institution on the example of Lviv Polytechnic National University and Danylo Halytsky Lviv National Medical University. Certain individuality of professional training of specialists in the pharmaceutical industry in the context of the acquirement of professional competencies in Good Pharmaceutical Practices based on the analysis of the educational-andprofessional and educational-and-scientific programs was disclosed.

\section{REFERENCES}

1. ISCED Fields of Education and Training 2013 (ISCED-F 2013), UNESCO Institute for Statistics, Montreal. URL: http://www.uis.unesco.org/ Education/Documents/isced-fields-of-education-training-2013.pdf.

2. Національна стандартна класифікація освіти, Національна академія педагогічних наук України. URL: http://naps.gov.ua/uploads/ files/sod/NSKO.pdf.

3. Про вищу освіту: Закон України від 01.07.2014 p. № 1556-VII. Дата оновлення: 16.01.2020. URL: https://zakon.rada.gov.ua/laws/show/ 1556-18.

4. Koster A., Schalekamp T., Meijerman I. Implementation of Competency-Based Pharmacy Education (CBPE). Pharmacy. 2017. Vol. 5(1). 10-26. doi:10.3390/pharmacy5010010.

5. Zubin A. Competency and its many meanings. Pharmacy. 2019. Vol. 7(2). P. 37. DOI: 10.3390/pharmacy7020037.

6. Parson L., Childs B., Elzie P. Using competency-based curriculum design to create a health professions education certificate program that meets the needs of students, administrators, faculty, and patients. Health Prof. Educ. 2018, Vol. 4, P. 207-217. DOI: 10.1016/j.hpe.2018.03.008

7. Standards and guidelines for quality assurance in the European Higher Education Area (ESG). Brussels, Belgium: European Association of Institutions in Higher Education. 2015. 27 p. URL: https://enqa.eu/ index.php/home/esg/.

8. Pearson, M, Hubball, H. Curricular Integration in Pharmacy Education. American Journal of Pharmacy Education. 2012. Vol. 76. P. 204-220. doi: 10.5688/ajpe7610204.

9. Pittenger, A, Chapman, S, Frail, C, Moon, J, Undeberg, M, Orzoff, J. Entrustable Professional Activities for Pharmacy Practice. American Journal of Pharmaceutical Education. 2016. Vol. 80. P. 57-65. doi:10.5688/ajpe80457. 
10. Гала Л.О. Постійний професійний розвиток фармацевтичних працівників - вимога належної аптечної практики. Управління та економіка в фармації. 2016. № 3 (47). С. 24-30.

\section{Information about authors: Krychkovska A. M.,}

Candidate of Pharmaceutical Sciences, Associated Professor of the Department of Technology of Biologically Active Substances, Pharmacy and Biotechnology

Lviv Polytechnic National University 12, Stepan Banders str., Lviv, 79013, Ukraine

Hubytska I. I., Candidate of Chemical Sciences, Associated Professor of the Department of Technology of Biologically Active Substances, Pharmacy and Biotechnology Lviv Polytechnic National University 12, Stepan Banders str., Lviv, 79013, Ukraine

Lopatynska O. I., Candidate of Pharmaceutical Sciences, Associated Professor of the Department of Clinical Pharmacy, Pharmacotherapy and Medical Standardization Danylo Halytsky Lviv National Medical University 69, Pekarska str., Lviv, 79010, Ukraine Associated Professor of the Department of Technology of Biologically Active Substances, Pharmacy and Biotechnology Lviv Polytechnic National University 12, Stepan Banders str., Lviv, 79013, Ukraine 